\title{
The Topkapi Palace Museum
}

\author{
A. Enis Cetin, Omer N. Gerek and Abmed H. Tewfik
}

A city-like ensemble overlooking the Marmara Sea and the Bosphorus, Istanbul's legendary Topkapi Palace became a synonym for Ottoman history and the heart of a far-flung empire for 400 years. Transformed into a museum, it houses a vast and disparate treasure. Presenting both the splendours of the palace and the richness of its collections on the Internet was the challenge described below. The authors, all with backgrounds in electrical engineering, are professionally involved in areas of advanced research in the new technologies. After having served as visiting associate professor at the University of Minnesota in the United States, A. Enis Cetin is a professor at Bilkent University in Ankara and chairman of the IEEE (Institute of Electrical and Electronics Engineers)EURASIP (European Association for Signal Processing) Nonlinear Signal and Image Processing Workshop, held in Ankara in June 1999. Omer N. Gerek is currently with the Signal Processing Laboratory of the Swiss Federal Institute of Technology-EPFL in Lausanne (on leave from the Department of Electrical and Electronics Engineering, Anadolu University, Eskisehir, Turkey). Abmed H. Tewfik is a professor of electronic communications at the University of Minnesota and was the first Editor-inChief of the IEEE Signal Processing Letters in 1993.

The map of Piri Reis showing part of Europe and the west coast of Africa, eastern, Central and South America and the Atlantic Ocean and islands. This is the oldest map known to include the North and South American continents.
The Topkapi Palace Museum Web page was created as a part of a National Science Foundation (NSF) research grant called 'Museum Audio-Visual Information Management System' given to Bilkent University in Ankara and the University of Minnesota. Topkapi Palace in Istanbul was not only the residence of Ottoman sultans but also the administrative centre of the
Ottoman Empire for four centuries. The first palace building was constructed in 1470 by Mehmet II (the Conqueror), and evolved into a large complex of buildings, annexes, courtyards and gardens until the reign of Abdulmecid I (1839-60). ${ }^{1}$ After the foundation of the Turkish Republic in 1923, the Topkapi Palace was renovated and transformed into a museum.

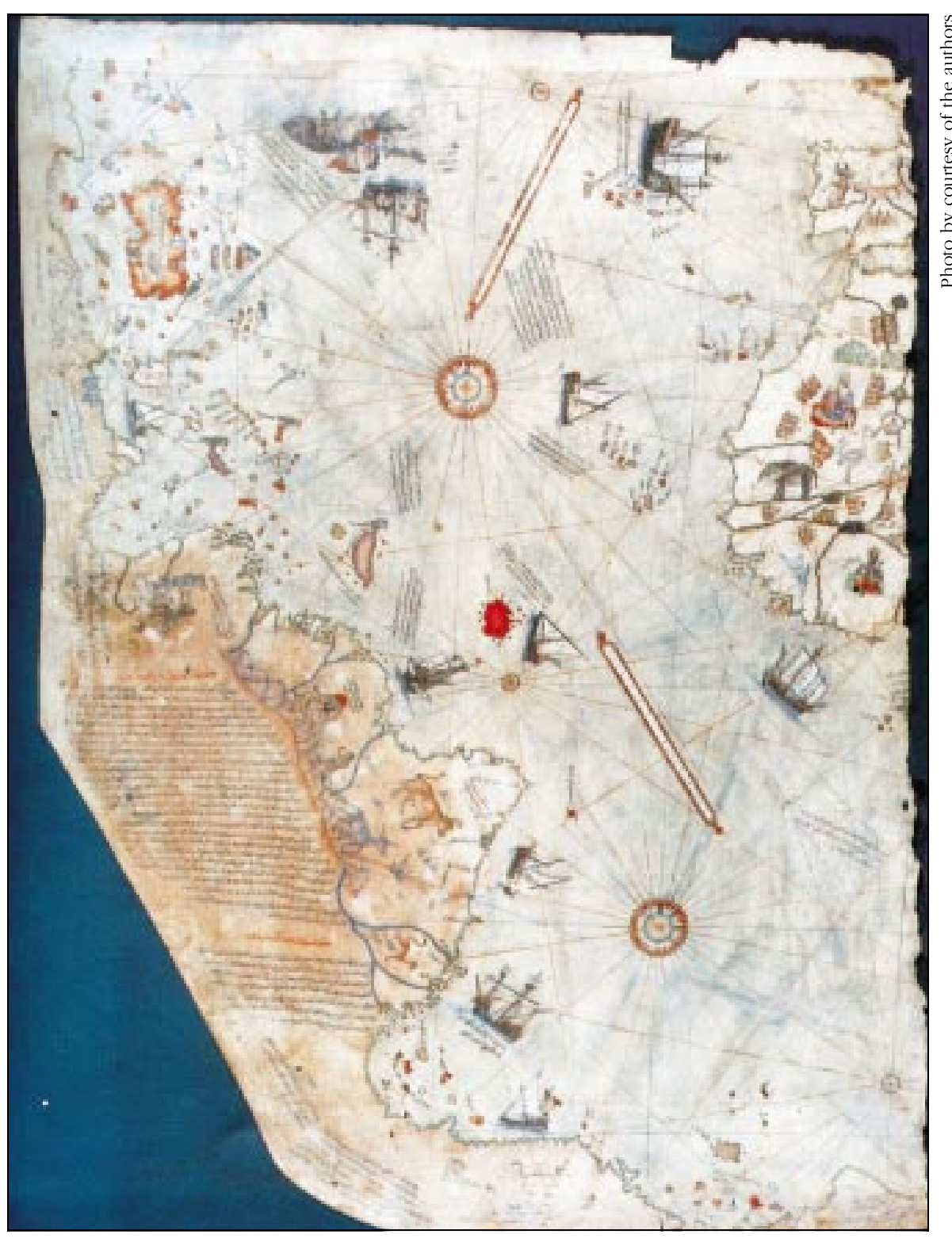




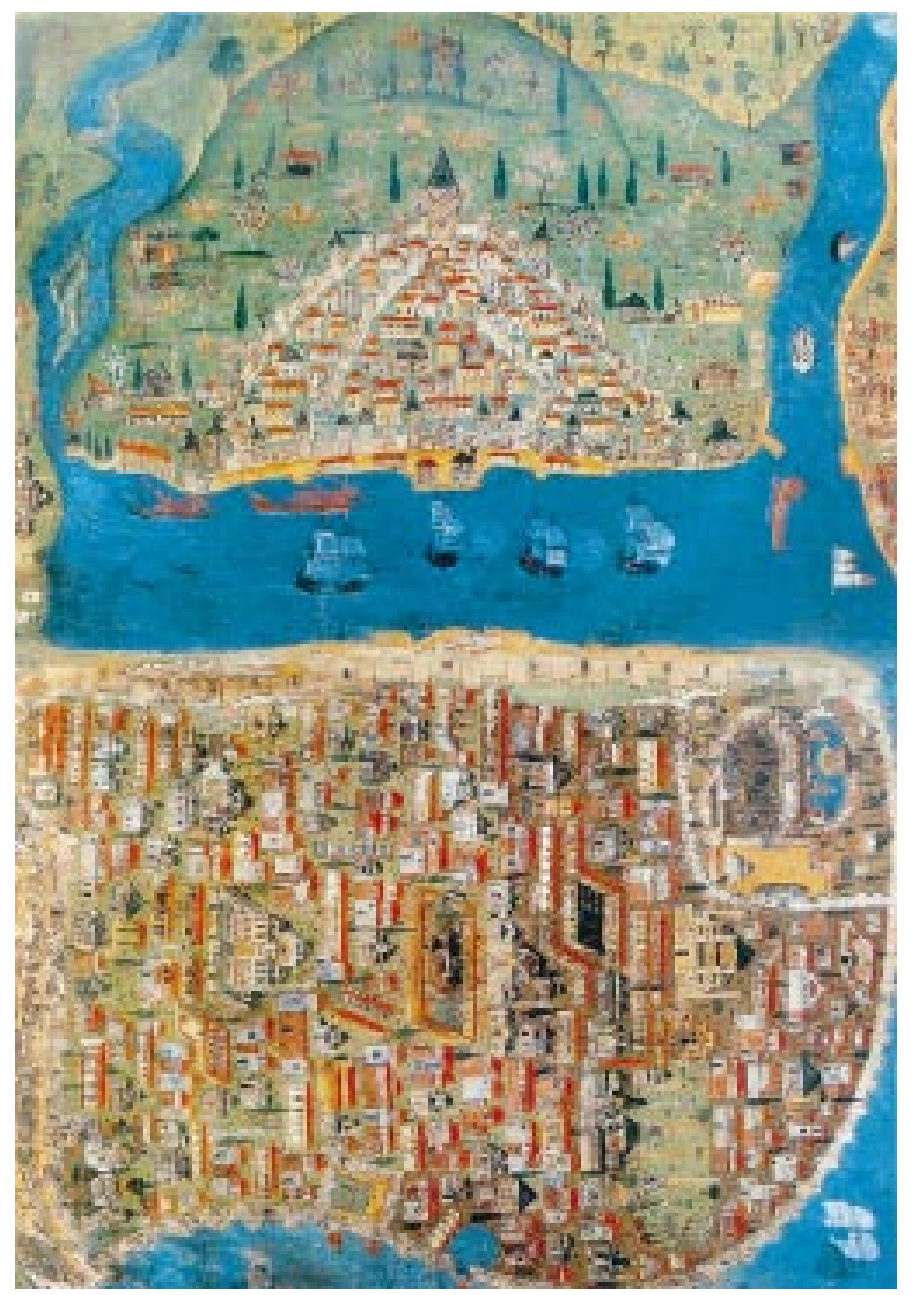

A fifteenth-century miniature plan of Istanbul by Matrakci Nasub. The Topkapi Palace is located at the entrance of the Golden Horn and the Bosphorus strait.

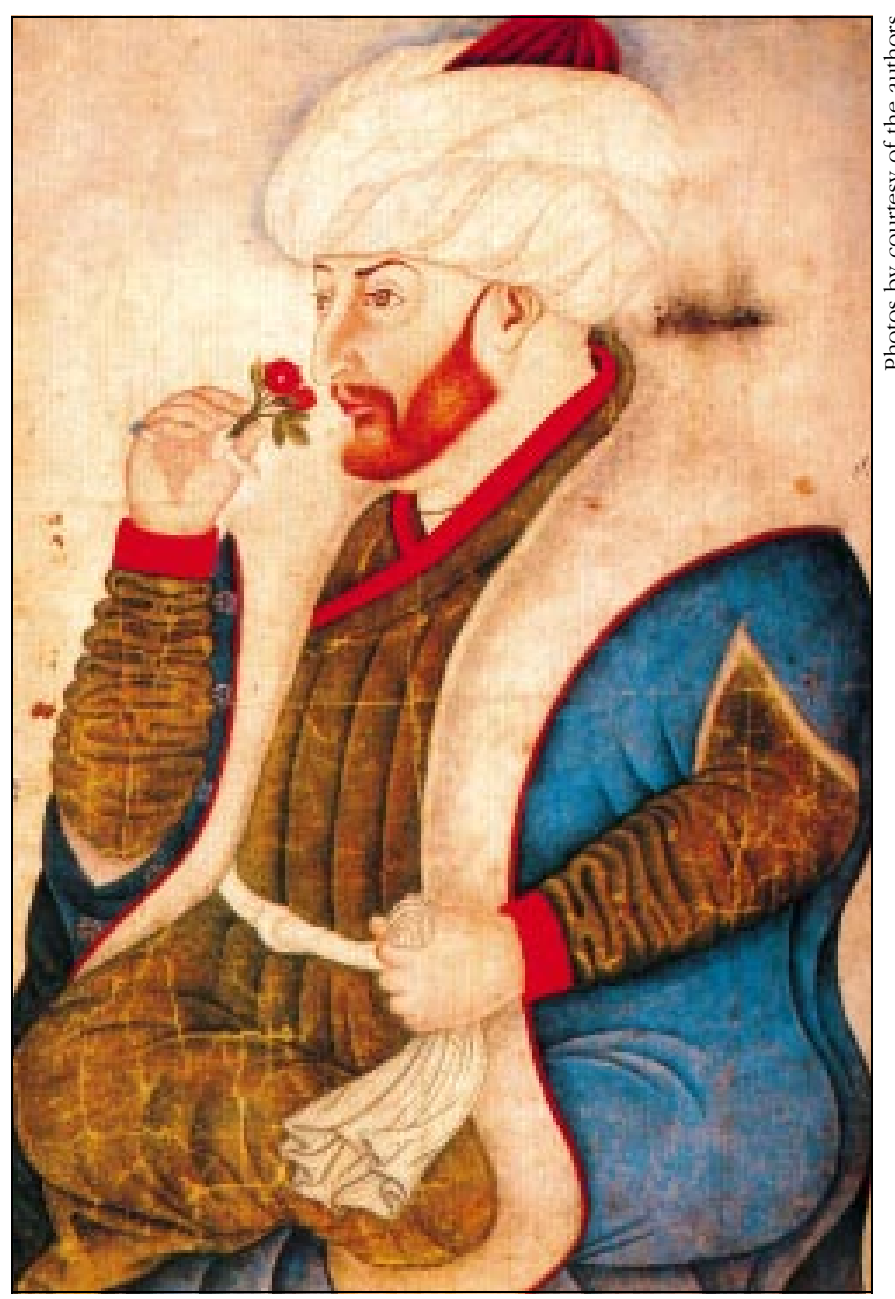

Fifteenth-century portrait of Sultan Mebmet II (the Conqueror), by Sinan Bey.
The Web site for the Topkapi Palace is under the Bilkent University host at http:// www.ee.bilkent.edu.tr/ history/topkapi. html, and serves an average of 1,000 visitors per month. Most of the images on 'virtual display' are digitized versions of documents, objects and pictures on exhibit in the Topkapi Palace. Due to the huge number of displayed and archived items, only a fraction of the museum's holdings could be digitized and put on the Web page.

The layout of the Web page is designed in a hierarchical manner. The opening part presents a brief history of the Topkapi Palace and the main section headings. Also, important keywords are marked as active fields, and by clicking on them the visitor can get detailed information about the location of the palace and the plan of the museum.

Main section headings are classified into three parts. In the first part, logistic information is provided under the following titles: Historical Background, Museum Contact and Visiting Information, Books and Documents About Topkapi Palace Museum, Guide to Topkapi Palace. ${ }^{2}$ 
The second part is organized according to the sections of the Topkapi Palace Museum:

Palace Attire and Garments: costumes of the sultans, and various kaftans, rugs, and textiles.

Imperial Treasury: well-known items of jewellery such as the spoonmaker's diamond, the Shah Nadir Throne and the Topkapi Dagger, along with pictures of the treasury halls.

Books, Maps and Calligraphic Documents: this link contains two sub-links, Koran Collection and Topkapi Scroll. Under the first, an article describes the Korans in the Topkapi Palace library and presents some sample images of the pages. The sub-link for the Topkapi Scroll contains images from a well-preserved document showing the theory and praxis of geometric design in Islamic architecture and ornament. This section also contains the Piri Reis map, the oldest known map to include the North and South American continents. It is drawn in colour on parchment and was executed by the Turkish geographer Piri Reis in the sixteenth century.

Miniature Paintings: miniatures found in illustrated copies of classic books and surviving fragments that are pasted or bound into albums. The first examples of Ottoman miniature paintings were produced under the patronage of Fatih Sultan Mehmet (Mehmet the Conqueror) in the mid-fifteenth century. This link contains nine sub-links: Early Islamic Illustrations; Secular Illustrations and Persian Paintings; Mongols and Paintings under the Jala'ir; Paintings in Persia under the Timurids; China, Chinoiserie and Painting in Turkestan under the Timurids; The Uzbeks and the Safavids; Book Illustration under the Ottomans; Turkish Miniatures in the sixteenth century; and Turkish-Islamic Art, the Miniatures of the Zubdat Al-Tawarikh. More than 100 high-quality images of sample miniatures are displayed, representing not only Ottoman works but also those of many different dynasties and regions within the Islamic world.

Portraits of the Sultans: miniature paintings of various Sultans, including Mehmet the Conqueror.

Clocks: pictures of various clocks used in the palace.

The Chambers of the Sacred Relics: this section of the palace is filled with the relics of the Prophet Mohammed brought there by Yavuz Sultan Selim I, upon the conquest of Egypt in 1517. These relics include personal belongings of Prophet Mohammed, such as his letters, mantle and swords.

Porcelains: a total of 10,700 Chinese and 730 Japanese porcelains ranging from the thirteenth to the twentieth century make the Topkapi Palace collection one of the most valuable in the world; several outstanding pieces are displayed here.

Guns and Armoury: this link is currently under construction and will contain pictures of the guns and uniforms of the janissaries.

The third part of the Web page is about the architecture and location of the museum. The Topkapi Palace is situated in one of Istanbul's most scenic locations, Sarayburnu (Seraglio Point). Since it was an evolving structure over time and space, it was not designed by a single architect and its style is consciously humble, avoiding monumental façades. In this part of the Web page, pictures from various gates, interior and exterior sections of the harem (the living quarters of the Ottoman 
sultans), the Baghdad Pavilion, the chambers of various sultans, baths, and courtyards as well as pictures of intricately decorated surfaces and walls can be accessed. The visitor can also view a live image of the Topkapi Palace as well as entrances of the Golden Horn and the Bosphorus strait from the Marmara Sea. The live image is obtained via a link in which a camera is placed on top of the Turkcell Plaza building in Istanbul.

A bibliography is also included. The visitor can find not only a list of books and papers about the Topkapi Palace but also access the links to various related Web sites as well as the catalogue of the Halil Inalcik collection at the Bilkent University library, which contains information about Professor Halil Inalcik's personal book and rare document collection on Ottoman and Turkish history.

The Web page provides a multi-resolution viewing capability. Initially, low resolution versions (thumbnail pictures) of the images are displayed. High resolution pictures can be viewed by clicking on them. The information content of the Topkapi Palace Web page is freely available; however, as some of the high-quality digitized pictures have commercial value, a way of preventing their unauthorized use is to embed digital watermarks in the images. ${ }^{3}$ Digital watermarks may be either visible or invisible and in the Topkapi Palace Web page invisible watermarks have been inserted in some of the images.

Recently, technical co-operation was established between the Topkapi Web page project and the European project, OCTALIS (Offer of Contents through Trusted Access Links), which aims to develop trading agencies for audiovisual data over the Internet. Reliable and secure communication agents are under development due to the copyright and commercial issues facing online museums and libraries. With the introduction of OCTALIS, the Topkapi Palace Web page intends to integrate a global approach to enable conditional access and efficient copyright protection by the use of digital watermarking for copyright protection and Secure Socket Layer (SSL) or Open Kernel for Access to Protected Interoperable Interactive Services (OKAPI) for secure data transmission including authentication of involved parties.

Acknowledgements. The authors would like to express their thanks to the Ministry of Culture and the Ministry of Foreign Affairs for letting them use the materials presented in the Web page, to Dr Engin Ozgen, former director General of the Museums and Historical Monuments, and to Dr Filiz Cagman, director of the Topkapi Palace Museum.

\section{Notes}

1. Gulru Necipoglu, Architecture, Ceremonial, and Power: The Topkapi Palace in the Fifteenth Century, New York, Architectural History Foundation, 1991; Ahmet Ertug, Topkapi: The Palace of Felicity, Istanbul, Ertug \& Koluk.

2. Murat Belge and Ara Guler, 'Guide to Topkapi Palace', Skylife, No. 138, October 1994.

3. Mitchell D. Swanson, Mei Kobayashi and Ahmed H. Tewfik, 'Multimedia DataEmbedding and Watermarking Technologies', Proceedings of the IEEE, Vol. 86, No. 6, pp. 1064-87, June 1998. 